\title{
"Como corderos entre lobos hambrientos". La literatura misional jesuita en las fronteras amazónicas del virreinato peruano entre finales del siglo XVII y comienzos del siglo XVIII*
}

\author{
José Luis BetrÁn MoyA \\ Universidad Autónoma de Barcelona \\ joseluis.betran@uab.cat
}

Fecha de recepción: 07/10/2013

Fecha de aceptación: 03/04/2014

\section{Resumen}

La segunda mitad del siglo XVII fue un momento de avance y consolidación de las misiones jesuitas en las fronteras septentrionales y orientales del virreinato peruano. Las experiencias de muchos de estos misioneros se han conservado a través de una abundante literatura misional redactada por los propios miembros de la Compañía de Jesús y que conoció una auténtica edad de oro durante esta etapa. Tomando como ejemplo algunas de las obras más emblemáticas, el artículo propone en análisis de algunos de los rasgos que definen la estructura narrativa de este género literario, tan importante en la actividad propagandística de las acciones evangelizadoras realizadas por los jesuitas en las tierras americanas

Palabras clave: Compañía de Jesús, literatura misional, virreinato del Perú, siglos XVII y XVII

\section{"Like sheep among hungry wolves". Jesuit missionary literature in the Amazonian borderlands of the Peruvian viceroyalty (late seventeenth and early eighteenth centuries)}

\begin{abstract}
The second half of the seventeenth century was a period of advance and consolidation for the Jesuit missions in the northern and eastern borderlands of the Peruvian viceroyalty. The experiences of many missionaries are preserved in a vast missionary literature written by the members of the Society of Jesus itself. This literature went through a genuine 'golden age' at the time. On grounds of some of its most emblematic works, this article proposes an analysis of some characteristics defining the narrative structures of this literary genre, which played an important role in the Jesuit propaganda on evangelization in South America.
\end{abstract}

Key words: Society of Jesus, missionary literature, Peruvian viceroyalty, sixteenth and seventeenth centuries

* Este trabajo forma parte del proyecto de investigación "Memoria y Cultura religiosa en el mundo hispánico. 1500-1835" (HAR 2011-28732-CO3-01) del Ministerio de Economía y Competitividad del Gobierno de España. 
Muchos de aquellos bárbaros tuvieron en los principios a los nuestros por hombres desvalidos a quienes la necesidad de vivir arrojaba a sus tierras para buscar en ellas su remedio, viéndolos tan pobremente vestidos y sin alhajas ni aparatos que veían en otros españoles. Otros indios más advertidos los juzgaron espías de los españoles, de que nacía el recelarse de ellos y a veces el intentar matarlos ${ }^{1}$.

Para Ignacio de Loyola la salvación de los próximos, entre los que también podían incluirse los más alejados de la fe, es decir los infieles y por ende los indios, era un fin principal del instituto que expresaba la importancia de la caridad fraterna como la mejor y más eficaz para el servicio de Dios ${ }^{2}$. La vocación misional de la Compañía de Jesús fue evidente ya desde sus Constituciones y se formalizó en el texto del general Claudio Acquaviva, De modo instituendarum missionum, de mayo de $1599^{3}$. El modelo se inspiraba en la experiencia novotestamentaria: de la misma manera que Jesús había enviado a sus apóstoles, el Papa, en tanto que supremo "Vicario de Cristo", enviaba a los jesuitas por todo el orbe a la plantatio ecclesiae 4 , haciendo realidad el espíritu universal del instituto que expresara Jerónimo Nadal con su fórmula totus mundos nostra habitatio fit ${ }^{5}$.

De los más de dieciséis mil religiosos que pasaron a la América española entre los siglos XVI y XVIII, una cuarta parte fueron jesuitas. Tras los franciscanos fueron el segundo instituto religioso en orden de importancia numérica en el Nuevo Mundo hasta su expulsión en $1767^{6}$. Establecidos inicialmente en los centros urbanos de importancia económica y política de los dos virreinatos, dedicándose primordialmente a la educación formal de sus élites españolas y criollas, su implantación territorial fue rápida y exponencial. En 1581, apenas nueve años después de su llegada a Nueva

1 Altamirano, D. F. (S.J.): Historia de la misión de los mojos, La Paz, Imprenta de El Comercio, 1891, p. 164.

2 Ignacio de Loyola: Obras completas, Madrid, 1952, pp. 370-371. Al respecto, Navas, A.: "San Ignacio como evangelizador y su incidencia en la orientación evangelizadora de los jesuitas en América", en Congreso Internacional de Historia. La Compañía de Jesús en América: Evangelización y Justicia. Siglos XVII y XVIII, Córdoba, Provincia de Andalucía y Canarias de la Compañía de Jesús, 1993, pp. 216-219.

3 Así se expresa en la Formula del Instituto en la versión de 1540, con clara alusión al cuarto voto de obediencia ciega a las órdenes papales: "[a ir] a cualquier región a que nos quieran enviar, aunque nos envíen a los turcos, o a cualesquiera otros infieles, incluso los que viven en las regiones que llaman Indias; o a cualesquiera herejes o cismáticos o a los fieles cristianos que sea". Arzubialde, S., Corella, J., García Lomas, J. M. (eds): Constituciones de la Compañía de Jesús, Bilbao, Sal Terrae, 1993, p. 58.

4 Corsi, E.: "Introducción", en Consi, E. (coord.): Órdenes religiosas entre América y Asia. Ideas para una historia misionera de los espacios coloniales, México, El Colegio de México, 2008, p. 29. Sievernich, M. (S.J.): "La Misión en la Compañía de Jesús: Inculturación y proceso", en Hernández Palomo, J. J. y Rodrigo Moreno, J. (coords.): La misión y los jesuitas en la América española, 1566-1767: cambios y permanencias, Sevilla, Escuela de Estudios Hispano-Americanos, 2005, pp. 265-287. Del mismo autor: "Conquistar todo el mundo: los fundamentos espirituales de las misiones jesuíticas", en Kohut, K. y Torales Pacheco, M. C. (eds.): Desde los confines de los imperios ibéricos. Los jesuitas de habla alemana en las misiones americanas, Frankfurt-Madrid, Vervuert-Iberoamericana, 2007, pp. 4-5.

5 Romano, A.: "Un espacio tripolar de las misiones: Europa, Asia y América", en Corsi, op. cit. (nota 4), pp. 256-257.

6 Ortega Moreno, M. y Galán García, A.: "Quienes son y de donde vienen: una aproximación al perfil prosopográfico de los jesuitas enviados a Indias (1566-1767)”, en Martínez Millán, J., Pizarro Llorente, H., Jimenez PABLo, E. (eds.): Los jesuitas, Religión, politica y educación (siglos XVI-XVIII), Madrid, Universidad Pontificia de Comillas, 2012, vol. 3, p. 1422. 
España, 107 jesuitas estaban instalados en las ciudades de México, Puebla de los Ángeles, Oaxaca, Veracruz, Valladolid (Morelia) y Páztcuaro ${ }^{7}$. Otros tantos trabajaban en el virreinato peruano, cifra que a la muerte del general Acquaviva en 1615 se había triplicado, repartiéndose por sus diversas audiencias: en la de Lima, además de la capital, en Cuzco y Arequipa; en la de Charcas, en los colegios de La Paz y Chuiquisaca y en las residencias de Potosí y Santa Cruz de la Sierra, además de las de Santiago de Estero (gobernación de Tucumán), Asunción (gobernación del Paraguay) y en las Audiencias de Quito y Santiago de Chile. Algunas de estas residencias se encontraban ya de por sí a una gran distancia de la capital virreinal, pero con el desplazamiento de los dominicos en 1576 de las misiones establecidas en torno al lago Titicaca (Juli y Chuchito), los jesuitas vivieron, además, su primera prueba misional en el extremo de la expansión española peruana. La experiencia allí adquirida resultaría trascendental para la apertura de unas nuevas fronteras misionales en los límites amazónicos del virreinato, sirviendo muchas de aquellas residencias como puertas a su entrada ${ }^{8}$.

La instalación de los jesuitas en el mundo americano fue paralela a la expansión de las primitivas fronteras virreinales, proceso todavía inacabado en el inicio del siglo XVII. La fragilidad de la potestad real en aquéllas atendía a varios motivos. Por un lado, la Corona se enfrentaba a la creciente presencia de otras potencias europeas en suelo americano -los portugueses, desde sus posesiones brasileñas, y ya en pleno siglo XVII, franceses, ingleses y holandeses desde la Guayana y algunas de las islas caribeñas del Atlántico venezolano-, que siempre fueron motivo de inquietud para las riquezas argentíferas peruanas por vías como la del contrabando ${ }^{9}$, y que para algunos religiosos, como el jesuita madrileño Juan de Rivero, suponían además una desventurada traslación de las fronteras de la herejía europea hasta el Nuevo Mundo ${ }^{10}$. Por otro lado, la constatación reiterada a lo largo del siglo XVI de los representantes de la Monarquía de lograr un sometimiento militar de los numerosos grupos indíge-

7 Decorme, G.: La obra de los jesuitas mexicanos durante la época colonial, 1572-1767, México, Antigua librería Robredo de José Porrúa e hijos, 1941, t. I, pp. 4-5.

8 Broggio, P.: Evangelizzare il mondo. Le misión della Compagnia di Gesù tra Europa e Amèrica (secoli XVI-XVII), Roma, Carocci, 2004, p. 104. Paralelamente los jesuitas perfilarían el mapa definitivo de su administración provincial en Ultramar. La provincia de Méjico vio en 1605 como se desgajaba de su gobierno la misión de Filipinas. La de Perú sufrió un proceso similar en 1604, cuando Paraguay se convirtió en provincia independiente. Tres años más tarde, en el norte, se fundó la provincia del Nuevo Reino de Granada. En 1616, por su amplitud geográfica, ésta se escindió para su mejor gobernación, con la creación de la de Quito. La dificultad de las comunicaciones a través de la cordillera de los Andes entre las tierras de Tucumán, Paraguay y Chile, llevaron también a la creación de esta última como provincia independiente en 1625. BURRIEZA SÁNCHEZ, J.: Jesuitas en Indias: entre la utopia y el conflicto. Trabajos y misiones de la Compañía de Jesús en la América Moderna, Valladolid, Universidad de Valladolid, 2007, pp. 60-61. La división de la primitiva provincia peruana significaría que ésta se separaría de gran parte de sus misiones fronterizas, desplazando así su identidad misionera hacia la periferia del virreinato, hacia un mundo de enormes extensiones geográficas, todavía entonces inexplorado, que servia de frontera teórica entre el espacio español y las potencias europeas que se fueron asentando en regiones próximas. Al respecto, MaldaVsKy, A.: Vocaciones inciertas. Misión y misiones en la provincia jesuita del Perú en los siglos XVI y XVII, Sevilla-Lima, CSIC-Instituto Francés de Estudios Andinos-Universidad Antonio Ruiz de Montoya, 2012, pp. 72 y ss.

9 Rey Fajardo, J. DEL (S.I.): "Geografía, territorio y nacionalidad. Misiones jesuíticas en la Orinoquia", en Martínez Millán y otros, op.cit. (nota 6), vol. 3, p. 1365.

10 Rivero, J. (S.I.): Historia de las misiones de los Llanos de Casanare y los rios Orinoco y Meta, Bogotá, Imp. de Silvestre, 1883, p. 100. (hay una edición con estudio introductorio a cargo R. Guerra Anzuola, publicada en Bogotá, Emprea Nacional de Publicaciones, 1956). 
nas que vivían en aquellas fronteras aconsejaría finalmente un cambio de estrategia. La posibilidad de que los indios pudieran ser instrumentalizados por los intrusos europeos o esclavizados por adelantados y encomenderos sin escrúpulos o por bandeirantes portugueses, terminaría convirtiendo a los misioneros en protagonistas de una política regia que buscaría a lo largo del siglo XVII no solo la evangelización de aquellas poblaciones sino también el alcanzar una cierta estabilidad política de aquellos confines.

Convertidos en hombres de frontera, instrumentos a la vez políticos y religiosos, la vocación misionera de los religiosos que se adentraron en aquellos inexplorados y dilatados parajes vino acompañada de una activa literatura divulgativa de sus experiencias y aventuras, que conocería una etapa dorada a partir de la segunda mitad del Seiscientos, cuando se aceleraron las entradas religiosas en el piedemonte amazónico, en el antiguo Antisuyu incaico, lo que los cronistas llamarían "la montaña", con el objetivo de fundar nuevas reducciones indígenas con carácter más estable. Se trata, en su conjunto, de un corpus importante de textos a caballo entre el discurso de ficción (imaginativo) y el discurso histórico (referencial), como ya señalaran en su día Michel de Certeau y Hayden White ${ }^{11}$, pero que ayudaron a descubrir y a identificar muchas de aquellas tierras y de los pueblos que las habitaban a sus potenciales lectores europeos. Aunque sólo una mínima parte llegarían a ser impresas, su valor histórico y etnográfico queda hoy fuera de toda duda ${ }^{12}$. Además de su indudable carácter edificante dentro del instituto, sirvieron de aval de la prolífica actuación religiosa de la Compañía contra la escalada creciente de críticas vertidas contra ella por sus adversarios tanto en los propios espacios coloniales como en las diferentes cortes europeas, demostrando como aquellas misiones itinerantes de los jesuitas peruanos cumplían impecablemente la vocación apostólica con la que había sido fundada ${ }^{13}$.

\section{LA DIFICIL ENTRADA}

En el Proemio de su De procuranda Indorum Salutate (Salamanca 1588/1589), el jesuita José de Acosta, partiendo de los precoces contactos de los jesuitas con las culturas amazónicas, clasificaba a muchas de ellas dentro de la categoría de las naciones bárbaras:

Viniendo ya a la tercera y última clase de bárbaros, es imposible decir el número de pueblos y regiones de este Nuevo Mundo que comprende. En ella entran los hombres salvajes, semejantes a las bestias, que apenas tienen sentimientos humanos. Sin ley, sin rey, sin pactos, sin magistrados ni régimen de gobierno fijos, cambiando de domicilio de tiempo en tiempo y aun cuando lo tienen fijo, más se parece a una cueva de

11 Certeau, M. De: La escritura de la Historia, México, Universidad Iberoamericana, 1993; White, H.: El contenido de la forma, Barcelona, Paidós, 1992.

12 Pino Díaz, F. Del: "Los métodos misionales jesuitas y la cultura de 'los otros"” en Hernández Palomo, op.cit. (nota 5), pp. 48 y ss.

13 PaVone, S.: I gesuiti : dalle origini alla soppressione, 1540-1773, Roma, Laterza, 2004, pp. 111 y ss. [ed. en castellano: Los jesuitas: desde el origen a la supresión, 1540-1773, Buenos Aires, Araucaria, 2007]. 
fieras o a establos de animales. A este grupo pertenecen en primer lugar todos aquellos que los nuestros llaman caribes; no ejercen otra profesión que la de derramar sangre, son crueles con todos los huéspedes, se alimentan de carne humana, andan desnudos cubriendo apenas sus vergüenzas. A este tipo de bárbaros alude Aristóteles cuando escribía que se les podía cazar como a bestias y domar por la fuerza. De ellos hay en el Nuevo Mundo innumerables manadas. Tales son los chunchos, los chiriguanás, los mojos, los iscaicingas, vecinos nuestros que conocemos; tales dicen ser buena parte de los pueblos brasileños y los de casi toda la Florida. Pertenecen también a esta clase aquellos bárbaros que, aún sin ser fieros como tigres o panteras, poco se diferencian, sin embargo, de los animales, también ellos desnudos, asustadizos y entregados a los más degradantes vicios de Venus o incluso de Adonis. Tales dicen ser los que los nuestros llaman moscas en el Nuevo Reino [de Granada], tal la gente que habita promiscuamente en Cartagena y a lo largo de todas sus costas y los que puebla las grandes campiñas del inmenso río Paraguay, así como la mayor parte de los pueblos que ocupan el espacio infinito que media entre los dos océanos aún no bien explorados pero de cuya existencia consta con certeza ${ }^{14}$.

Buena parte de la historia colonial iberoamericana de los siglos modernos estuvo marcada por un concepto de frontera entendido como espacio físico y sociológico, basado en interacciones entre sociedades nativas independientes y un frente poblador heterogéneo, con componentes europeos, mestizos e indígenas. Se trataba, en palabras de John Elliott, de regiones porosas en "donde las necesidades de supervivencia por ambas partes encontraban su expresión en la violencia y la brutalidad, pero también en la cooperación y el acuerdo mutuo" 15.

Tras la conquista de los grandes imperios, los incentivos ibéricos de penetración en tierras desconocidas se movieron por la ambición de encontrar oro y otros metales o productos (como las especias) preciosos. Como escribía el jesuita extremeño Diego de Samaniego, uno de los primeros misioneros jesuitas en llegar en 1586 a la misión fronteriza oriental peruana de Santa Cruz de la Sierra, la noticia de los metales ponía "alas en los pies de los españoles para ir adelante" 16 . En esta búsqueda ansiosa desempeñaron un gran papel los sueños fantasiosos de tesoros fabulosos, nacidos del imaginario medieval que despertaban la ambición de los conquistadores y que cuando coincidieron o se superpusieron con los mitos indígenas como el Gran Mojo, el Paititi o el Dorado, provocaron el movimiento de centenares de expediciones lanzadas desde puestos avanzados como aquél, fundado en 1560 por el capitán Ñuflo de Chaves ${ }^{17}$. Aunque muchas de aquellas expediciones contribuyeron a aliviar la tensión

\footnotetext{
14 Acosta, J. DE: De procuranda indorum salute, ed. de Luciano Pereña, Madrid, CSIC, 1984, vol. I, pp. 68-69.

15 Elliott, J. H.: Imperios del mundo atlántico. España y Gran Bretaña en América (1492-1830), Madrid, Taurus, 2006, p. 405.

16 Citado por Lasso Varela, I. J.: Historia de una Relación: Chiquitos, cruceros y jesuitas en el escenario de la gobernación de Santa Cruz de la Sierra, 1561-1767, Loja, Universidad Técnica particular de Loja, 2010, p. 55. El padre Samaniego nos dejó una relación de su temprana actividad misional jesuita en estas tierras: Relación del P. Samaniego con muchas noticias sobre misiones hechas a los itanes, chiriguanas y chiquitos, en Mateos, F.: Historia General de la Compañía de Jesús en la provincia del Perú, Madrid, CSIC, 1944, pp. 481 y ss.

17 Livi Bacci, M.: El Dorado en el Pantano. Oro, esclavos y almas entre los Andes y la Amazonia, Madrid, Marcial Pons, 2012, pp. 61-78. Sobre el caso de Santa Cruz de la Sierra consúltese la obra de GARCÍA RECIO, J.
} 
política y militar interna en el centro de los nacientes virreinatos, en su mayoría se convirtieron en entradas imposibles, condenadas al fracaso y en ocasiones a la muerte de sus partícipes. Fueron, en cierta medida, "el reverso de la Conquista, la revancha de la autoctonía sobre la invasión europea"18.

La presencia de jesuitas en estas expediciones, deseosos de extender la conquista espiritual a un sinfín de pueblos todavía por evangelizar, no fue infrecuente ${ }^{19}$. Aunque hubo unos comienzos prometedores en estas entradas de algunos misioneros jesuitas en los últimos años del siglo XVI y los iniciales del siglo XVII, no fue hasta bien adentrada la segunda mitad de esta última centuria que culminarían satisfactoriamente algunos de aquellos intentos de fundar misiones permanentes en los espacios fronterizos del norte y este del virreinato peruano. La carencia de efectivos hasta bien avanzado el siglo en que mejoraría la situación con la creciente incorporación de criollos y mestizos americanos a la orden, así como el deseo de los provinciales peruanos por evitar la dispersión de los misioneros y la falta de control sobre unos territorios cada vez más extensos pueden ayudar a explicar el lento desarrollo que las misiones tuvieron hasta entonces ${ }^{20}$.

Por la amplitud territorial y por su naturaleza selvática, las vías fluviales fueron caminos imprescindibles de la penetración misionera ${ }^{21}$, convirtiendo a los religiosos en pioneros en el descubrimiento de tierras hasta entonces ignotas para los europeos ${ }^{22}$. Por el norte, los esfuerzos se encaminaron en dos direcciones. Desde el colegio de Quito, fundado en 1596, el jesuita catalán Rafael Ferrer inició ya en 1605 las primeras entradas en la selva amazónica a través de los ríos Aguanico y Napo. Además de dejarnos un Compendio de doctrina cristiana en lengua Cofane, destacó por su lucha contra la imposición de tributos de los indígenas, entre los que fundó, entre los años 1604 y 1605, las reducciones de San Pedro, Santa Marta y Santa Cruz, que duraron hasta su muerte en 1610, victima de unos encomenderos que le precipitaron sobre el río Cófanes, uno de los afluentes del Aguanico, mostrando el precio que algunos jesuitas pagaron por su defensa del indio frente a la codicia de algunos españoles ${ }^{23}$.

La atribución del mérito sobre la primera evangelización de la cuenca del Amazonas supuso una dura pugna historiográfica con los franciscanos ${ }^{24}$. El jesuita Cristóbal

M.: Análisis de una sociedad de frontera. Santa Cruz de la Sierra en los siglos XVI y XVII, Sevilla, Diputación Provincial del Sevilla, 1988.

18 SaIgnes, T.: "Las zonas conflictivas: fronteras iniciales de guerra", en Historia General de América Latina, 9 vols., Madrid-París, Trotta-Unesco, 1999-2008, vol. 2, p. 269.

19 Coello de la Rosa, A.: "Los jesuitas y las misiones de frontera del alto Perú: Santa Cruz de la Sierra (1587-1603)", Revista Complutense de Historia de América, 33 (2007), pp. 151-171.

20 MaLDAVSKY, op. cit. (nota 8), pp. 80-81.

21 Rey Fajardo, J. Del (S.I.): "José Gumilla, explorador científico de la Orinoquia”, en Plazaola, J. (ed): Jesuitas exploradores, pioneros y geógrafos, Bilbao, Mensajero, 2006, p. 201.

22 Medina, F. DE B. (S.I.): “¿Exploradores o evangelizadores? La Misión de los Mojos: cambio y continuidad (1667-1676)", en Hernández Palomo, op. cit. (nota 5), pp. 187-230.

23 Astraín, A. (S.I.): Historia de la Compañia de Jesús en la Asistencia de España, Madrid, Razón y Fe, 1902-1920, vol. 6, pp. 577-580.

24 Fr. José de Maldonado fue autor de una Relación del descubrimiento del río de las Amazonas, por otro nombre Marañón, hecho...por medio de los religiosos de San Francisco de Quito, de la que se imprimieron algunos ejemplares en 1641. Diez años después que Maldonado, otro franciscano, Fr. Laureano de la Cruz, repitió lo ya narrado por el anterior en su Nuevo descubrimiento del río de Marañón llamado de las Amazonas, 
de Acuña fue el que hizo la primera descripción detallada de todo el curso del río, al acompañar al capitán portugués Pedro de Texeira en su retorno al Brasil en 1639, en un viaje iniciado en el río Napo y concluido en Pará. Cuando al año siguiente viajó a Madrid, Acuña publicó un libro que llevaría por título el Nuevo descubrimiento del gran río de las Amazonas, fruto de sus observaciones y de un memorial adjunto que presentó al Consejo de Indias en 1641. Sus apenas cuarenta y seis folios se iniciaban con una dedicatoria al conde-duque de Olivares, al que calificaba de "atlante" por su patrocinio de "tan grandiosa empressa, de que depende la conversión de infinitas almas, el acrecentamiento de la Real Corona, y la defensa, y guarda de todos los tesoros del Perú?". La grandeza del imperio alcanzado con este descubrimiento, a su juicio, podía ser considerado similar al de China, pues era "espacio de casi quatro mil leguas de contorno", que encerraba "mas de ciento y cinquenta naciones de lenguas diferentes, suficientes cada una dellas a hazer por si sola un dilatado Reyno, y todos juntos un nuevo y poderoso Imperio". Acuña mostraba su disposición personal y la de la Compañía de Jesús para su conquista ${ }^{25}$. Después de informar que se trataba de un río diferente al Marañón, describía con todo detalle las costumbres de los indígenas -algunos de ellos antropófagos- y el clima, flora y fauna de las regiones amazónicas, datos que en muchas ocasiones obtuvo de los pueblos topinambos, llegando incluso a afirmar que en sus riberas existían verdaderas amazonas, de donde luego tomaría el nombre el río ${ }^{26}$.

Los jesuitas se interesaron, asimismo, por la cuenca del río Marañón a partir de 1632, fecha en la cual viajó a España y Roma el jesuita Francisco Fuentes en calidad

que escribió en Quito el año 1651. El manuscrito permaneció inédito en la Biblioteca Nacional de Madrid (Ms. 2950) hasta 1878, cuando lo imprimió en Prato Fr. Marcelino de Civezza. De nuevo se publicó en Quito, en 1942, como vol. VII de la "Biblioteca Amazonas". Entre otras muchas cosas habla de las misiones franciscanas entre los indios omaguas, con los que el autor vivió tres años, y del viaje del portugués Pedro Texeira, que remontó el Amazonas desde Curupá, subiendo luego por el Payamini y su afluente el Punin hasta Ávila, donde termina el viaje fluvial, que duró desde octubre de 1637 a junio de 1638 . Por primera vez se había navegado aguas arriba del gran río. El jesuita Rodrigo de Barnuevo, en réplica a Maldonado, escribiría una Relación Apologética así del antiguo como del nuevo descubrimiento del río de las Amazonas hecho por los religiosos de la Compañía de Jesús y nuevamente adelantado por los de la Seráfica Religión de la misma provincia, que permaneció inédita hasta 1942 (está incluida en Informes de jesuitas en el Amazonas, Iquitos, IIAP-CETA, 1986, pp. 109-135). Se proponía demostrar que los jesuitas habían hecho ya diez entradas en la hoya amazónica, en tierras de los indios encabellados, abijiras y omaguas, antes de que llegaran los franciscanos, continuando su explicación de esta penetración hasta el momento en que escribía, a mediados del siglo XVII. Sobre Barnuevo, véase Mercado, P.: Historia de la Provincia del Nuevo Reino y Quito de la Compañia de Jesús, Bogotá, Empresa Nacional de Publicaciones, 1957, vol. 3, pp. 192-199.

25 Acuña, C.: Nuevo Descubrimiento del Gran Rió de las Amazonas, Madrid, Imprenta del Reyno, 1641. Una versión más amplia sería publicada más tarde (reeditada en el tomo II de la "Colección de Libros que tratan de América, raros y curiosos”, Madrid, Imprenta de Juan Cayetano García, 1891).

26 Se cree, posiblemente sin fundamento, que la pérdida del Brasil tras la rebelión portuguesa llevó a esconder todos los ejemplares de esta obra, haciéndose tan rara hallarla que costó encontrar ejemplar para la traducción que Mazarino encargó en 1655 al académico francés Gomberville. Así lo insinúa el Padre Manuel Rodríguez Villaseñor, jesuita colombiano, que reprodujo una gran parte de la obra de Acuña en su obra $E l$ Marañon y el Amazonas. Historia de los descubrimientos, entradas y reducciones de Baciones. Trabajos malogrados de algunos conquistadores así temporales como espirituales publicada en Madrid, Antonio González de Reyes, 1684, justamente el año de su muerte, cuando desempeñaba el cargo de procurador general de Indias en Cádiz (hay edición moderna con el título, El descubrimiento del Marañón, Madrid, Alianza Editorial, 1990). 
de procurador con el fin de solicitar del general de la Compañía y del Consejo de Indias la autorización para fundar allí nuevas misiones ${ }^{27}$. El colegio de Cuenca fue la puerta de entrada hacia la región de Mainas. Los dos primeros jesuitas llegaron en 1638, estableciendo una primera residencia en el pueblo de Borja (fundado en 1619 por los españoles en busca de oro), desde la que se dedicaron a la evangelización de los indios encomendados a los españoles a lo largo del río. El primer pueblo fundado se llamó Limpia Concepción de Geveros, en referencia a la etnia de los reducidos geveros. La expansión geográfica de la misión estuvo determinada por la necesidad de comunicar el territorio de Mainas con Quito, circunstancia que llevó en 1654 al jesuita Raimundo de Santa Cruz a descender por el Marañón hasta el río Napo y remontar este último hasta llegar a Quito. A raíz de esta expedición se redujeron las parcialidades de los romainos, zaparas, aguanos y los manicuros que vivían a lo largo del rio Pastaza y los jesuitas de Mainas anexionaron el curato de Archidona, que, además de ser parroquia de indios, se convirtió en punto estratégico para el suministro de las misiones desde Quito, cuyo viaje podía durar medio año. En 1651 el número de misioneros en Mainas era de siete, todos provenientes de Quito, siendo dos, criollos. En 1653 las misiones fundadas eran ya doce. De ahí a 1730 crecieron hasta veintidós, con 5194 indígenas bautizados y 748 catecúmenos. Entre los jesuitas que misionaron la región conservamos los testimonios de Francisco de Figueroa ${ }^{28}$, el padre Maroni ${ }^{29}$, o Bernardo Recio y Manuel de Uriarte, estos dos últimos ya en el siglo XVIII ${ }^{30}$.

La segunda gran zona de proyección misional jesuita en el norte del virreinato fue la región de los Llanos, en el Nuevo Reino de Granada, gobernado por el presidente de una audiencia que en 1717 sería elevada a virreinato. Los Llanos eran grandes planicies situadas entre los ríos Meta y Arauca, entre la cordillera andina y el Orinoco. Las misiones se desarrollan a lo largo de las cuencas de tres grandes ríos: el Orinoco, su afluente el Meta y el afluente de éste, el Casanare, que recorrían la región. En 1624 el arzobispo de Santa Fé, Hernando Arias de Ugarte, confió esta zona a la Compañía de Jesús, entregándole la misión de Chita, hasta entonces en manos del clero diocesano. Cinco jesuitas trabajaron en esta reducción hasta que el sucesor de Ugarte les

27 Astraín, op. cit. (nota 22), vol. 5, p. 442.

28 FigueroA, F.: "Relación de las Misiones de la Compañía de Jesús en el país de los Maynas", Biblioteca Nacional de España, Madrid (BNE), Ms. 13.530, que aquí seguimos. Existe una edición de Manuel Serrano Sanz, impresa en Madrid en 1904 y, más recientemente ha sido editado en Informes de jesuitas en el Amazonas, op. cit. (nota 24), t. I, pp. 143-309.

29 Maroni, P.: Noticias auténticas del famosos río Marañón y misión apostólica de la Compañia de Jesús en la provincia de Quito en los dilatados bosques del dicho río, escribíalas por los años de 1738 un misionero de la misma Compañía, ed. de Jean-Pierre Chaumeil, Iquitos, IIAP, 1988.

30 Ambos redactaron sendos tratados sobre su experiencia misional ya en su exilio. El jesuita Bernardo Recio escribió en Roma una Compendiosa relación de la cristiandad de Quito (ed. moderna de C. Garcia Goldaraz, Madrid, CSIC, 1947). Por su parte, el vitoriano Manuel Joaquín Uriarte Ramírez fue autor de un Diario de un misionero de Mainas, redactado en 1771 (ed. moderna de C. Bayle, Madrid, CSIC, 1952), que es una autentica enciclopedia del bajo Marañón, debido a su impresionante memoria. Aunque escribe en la segunda mitad del siglo XVIII, interesa también nombrar la obra del vallisoletano José Chantre Herrera, un jesuita que nunca estuvo en América pero que realizó una excelente síntesis de los trabajos misionales de la Compañía en la cuenca del Amazonas, que tituló Historia de las misiones de la Compañía de Jesús en el Marañón español. La obra, que abarca los años 1637-1767, permaneció inédita hasta 1901, año en que se imprimió en Madrid. 
retiró la confianza en 1628, momento en que la abandonaron. Las misiones no se reemprendieron hasta la segunda mitad del siglo. En 1661 el provincial Hernando Cabero, con el beneplácito de las autoridades civiles y eclesiásticas de Santa Fé, envió a Ignacio Cano, Juan Fernández Pedroche y Alonso de Neira, a los que se unió el francés Antonio Bois-Le-Vert (castellanizado como Monteverde). Los misioneros fundaron las misiones de Pauto, Tame, San Salvador de Casane, Nuestra Señora del Pilar de Patute y Macaguane. A partir de 1666 los jesuitas se expandieron hacia el río Meta, fundando varias reducciones en el río Orinoco. Los indígenas evangelizados fueron al principio sobre todo achaguas y tunebos, extendiéndose más tarde a guahivos y sálivas. Desde estas regiones los jesuitas Ignacio Fiol y Felipe Gómez exploraron los márgenes del río Orinoco en 1679, llegando a fundar una misión en 1680 en la isla de los Adoles. En 1684 Fiol fue muerto por los indios caribes, que incursionaron en la región destruyendo las poblaciones fundadas por aquéllos. Una nueva invasión caribe en 1685 (apoyada por holandeses, franceses e ingleses) les obligaría a replegarse a Casanare, no logrando estas misiones un nuevo impulso hasta 1715 con la intervención del religioso José Gumilla, que fundaría en 1717 la reducción de San Ignacio, a la que siguieron las de Guanapalo, Santa Teresa, San José, Santísima Trinidad y San Joaquín, básicas para dar salida al mar desde los Llanos, dadas las malas comunicaciones por la cordillera andina con Bogotá.

Fue ésta una misión difícil por varias circunstancias: extremidad climatológica, dificultad de comunicaciones, aislamiento, rusticidad indígena, nomadismo, desconocimiento lingüístico, problemas con los encomenderos, invasiones caribes, etc...). De los 153 jesuitas que tuvo la misión, solamente el $43 \%$ permaneció en ella entre 1 y 4 años y solo el 22,88\% más de 30 años, siendo una cuarta parte de ellos originarios de Francia, Italia y las regiones católicas del sur de Alemania y Bohemia ${ }^{31}$. La historia de las misiones en esta región colombiana se restableció a comienzos del siglo XVIII. Fue entonces cuando la escribió el ya citado Juan de Rivero, que misionó en ellas a partir de 1721, escribiendo en 1736 su Historia de las misiones de los Llanos de Casane y los ríos Orinoco y Meta, obra que permaneció manuscrita hasta siglo y medio después. Crítica con el comportamiento de los españoles, la obra fue esencial para que el también jesuita José Cassani publicara en 1741 una Historia de la Compañia de Jesús del Nuevo Reino de Granada ${ }^{32}$, al parecer una obra de encargo de la propia orden para la que se sirvió de aquélla y de la historia provincial del jesuita Pedro Mercado. Poco después, el ya mencionado José Gumilla, describió también las misiones de que fue superior en su obra El Orinoco Ilustrado. Historia natural, civil y geographica de este gran río y de sus caudalosas vertientes: gobierno, usos y costumbres de los indios sus habitadores, con nuevas y útiles noticias de Animales, Árboles, Frutos, Aceytes, Resinas, Yerbas, y Raices medicinales; y sobre todo, se hallarán conversiones muy singulares a N. Santa Fé, y casos de mucha edificación, publicada en Madrid en 1741.

31 Rey FAJARDo, J. DEL (S.I.). “Aportes para el estudio de cambios y permanencias en las misiones jesuíticas de la Orinoquia”, en Hernández Palomo, op. cit. (nota 5), pp. 123-124.

32 Cassani, J. (S.I.): Historia de la Compañía de Jesús del Nuevo Reino de Granada, Madrid, Manuel Fernández, 1741. 
Por último, en las tierras orientales del Alto Perú, a partir del año 1674 y hasta la expulsión, los jesuitas estuvieron presentes en el actual territorio del departamento boliviano del Beni, donde formaron las misiones de Mojos. Aunque el proceso de formación de estas reducciones, dependientes de la provincia jesuítica del Perú, comenzó débilmente en los últimos años del siglo XVI, no se reemprendió hasta 1667, cuando el jesuita Juan de Soto desde la ciudad de Santa Cruz de la Sierra, lugar frecuentado por los indios para el intercambio de sus productos por herramientas, se dirigió de nuevo al territorio de Mojos ${ }^{33}$. Entre 1668 y 1674 los jesuitas hicieron varias entradas, generalmente bajo escolta militar, que desde el asentamiento temporal de Santísima Trinidad les permitió reconocer la geografía mojeña, que por entonces tenia 80 pueblos con 4895 personas $^{34}$. En 1676 fueron enviados los padres Pedro Marban, Cipriano Barace y el hermano José del Castillo, que tres años más tarde comenzaron a reunir a los indios en una primera reducción estable, ubicándola en un lugar alto para evitar las inundaciones anuales que sufría la región por los desbordes de las aguas que descendían desde la cordillera de los Andes y desde las sierras del Brasil, especialmente durante el verano ${ }^{35}$. En 1682 se fundó la misión de Loreto, con 600 indios bautizados, después de casi siete años de andanzas itinerantes de los jesuitas por la región. La misión fue el modelo que seguirían las nueve restantes que se fundarían antes de 1700 (Santa Trinidad, San Ignacio, San Francisco Javier, San José, San Francisco de Borja, Desposorios de Nuestra Señora, San Miguel, San Pedro Apóstol y San Luis Gonzaga) ${ }^{36}$.

Las misiones de Mojos recibieron un nuevo impulso en el año 1700, con la visita del jesuita madrileño Diego Francisco de Altamirano por encargo del Provincial. Por entonces contaban ya con un total de 13.500 indios reducidos. La visita supuso un avance cualitativo, pues los misioneros concluyeron imprimir en Lima una gramática en lengua moja, realizada por el padre Marban, con el fin de difundir esta lengua entre los indios que hablaban otras y convertirla en la principal en su interlocución con aquellos $^{37}$. A partir de este momento, aparecieron en todas las reducciones pequeñas escuelas que propiciarían la educación de los niños, para lo que se imprimieron 8000 cartillas en lengua moja ${ }^{38}$. Aunque no resultaba del gusto a las autoridades de la Corona que la catequización se realizara exclusivamente en la lengua india, los jesuitas

33 Medina, F. DE B. (S.I.): “¿Exploradores o evangelizadores? La misión de los Mojos: cambio y continuidad (1667-1676)", en Hernández Palomo, op. cit. (nota 5), p. 198.

34 Astraín, op. cit. (nota 22), vol. 6, p. 545.

$35 \mathrm{Si}$ bien es cierto que los jesuitas al llegar trataron de visitar los pueblos de la región en época seca, muy pronto se dieron cuenta que cuando la zona no estaba inundada, los indios se encontraban cazando o pescando sin tener un lugar fijo de residencia, lo que hacía más difícil su acción inicial de contacto. En cambio cuando las aguas del río Mamoré se desbordaban de su cauce e inundaban sus amplios márgenes, cada uno de los indios se replegaba a una de las lomas artificiales donde un grupo de familias de cada tribu se mantenía sin mucha humedad. Aprovechando esta situación y usando rústicas canoas, fabricadas de un solo tronco, los jesuitas se movilizaron más fácilmente y su labor fue más positiva porque pudieron encontrar un mayor número de oyentes reunidos en las lomas. PINTO PARADA, R.: "El panorama geográfico que encontraron los jesuitas en Mojos", en Simposio sobre las misiones jesuitas en Bolivia, La Paz, Ministerio de Relaciones Exteriores y Culto, 1987, pp. 56-57.

36 Altamirano, op. cit. (nota 1), pp. 67-69.

37 Ibidem, p. 83.

38 Ibidem, p. 84. 
siempre defendieron que su familiaridad facilitaba mejor el aprendizaje de los rudimentos del catecismo que de hacerlo en castellano ${ }^{39}$. Además, Altamirano trató de reforzar los puntos débiles que presentaban las misiones en el orden social y material. De esta manera se introdujo el gobierno secular, materializado en el cabildo indígena, con el fin de que los indios aprendieran a gobernarse por sí mismos ${ }^{40}$. También fue resultado de su visita el desarrollo de la agricultura, hasta entonces muy precario. Se potenciaron los cultivos de yuca del Paraguay para la fabricación del pan, la caña de azúcar, legumbres y arroz, además de algodón para la fabricación de tejidos. Los indios aprendieron además el manejo de los bueyes para arar la tierra, lo que facilitó su vida sedentaria y con ello el éxito de las misiones ${ }^{41}$. El misionero navarro Cipriano Barace fue el encargado de traer el primer ganado vacuno a Mojos desde Santa Cruz de la Sierra en 1682, en un viaje que duró dos meses ${ }^{42}$. En 1708 comenzaron los jesuitas también en esta región la conversión de los belicosos baures, que unos años antes habían matado al mismo Barace, y la de los mobimas. Aunque también lo intentaron con los belicosos chiriguanos, que se extendían a lo largo de las estribaciones de los Andes con el río Pilcomayo por el sur y el Guapay por el norte, limitando con el Paraguay, en este caso fracasaron, a pesar que la Corona precisaba la pacificación de estas tribus para asegurar las comunicaciones entre el Perú y el Tucumán ${ }^{43}$.

En total, durante los siglos XVII y XVIII los misioneros jesuitas fundaron en las vastas selvas del oriente boliviano próximas a las fronteras brasileñas 15 pueblos en la región de los mojos (1681-1767) y 11 en la región de chiquitos (1691-1767), con la experiencia acumulada de más de ochenta años en tierras guaraníes y otros lugares de América. Numerosos son los testimonios escritos que conservamos del contacto que los jesuitas mantuvieron con estos grupos étnicos ${ }^{44}$. Los principales cronistas jesuitas sobre las misiones de Mojos fueron los peruanos Diego de Eguíluz ${ }^{45}$ y Antonio de Orellana ${ }^{46}$ y los españoles Julián Aller, Pedro Marbán y Diego Francisco Altamirano. Sobre las misiones de los Mojos escribiría también, ya en el exilio a finales del siglo XVIII, el misionero jesuita eslovaco Ferc Xaver Éder su Descritio provinciae moxitarum in regno peruano (Buda, 1791) ${ }^{47}$. Sobre el mundo de los indios chiquitos, próxi-

39 Ibidem, p. 85. Lasso, op. cit. (nota 16), p.14

40 Altamirano, op. cit (nota 1), pp. 86 y ss.

41 Ibidem, p. 89.

42 Ibidem, p. 59.

43 LASso, op. cit. (nota 16), pp. 360-377.

44 Barnadas, J. M. y Plaza, M. (eds): Mojos. Seis relaciones jesuiticas. Geografia-EtnografiaEvangelizacion, 1670-1763, Cochabamba, Historia Boliviana, 2005.

45 Eguíluz, D. De (S.I.): Relación de la missión apostólica de los Moxos en la Provincia del Perú de la Compañía de Jesús, Lima, s.n., 1696. Al respecto, véase la introducción a la edición de su obra por parte de E. Torres Saldamando, incluida en Historia de la misión de los Mojos en la República de Bolivia, escrita en 1696 por el padre Diego de Eguíluz, Lima, Imprenta del Paraíso, 1884.

46 Orellana, A. DE (S.I.): Relacion sumaria de la vida y dichosa muerte del V. P. Cipriano Barace, natural de la villa de Isaba, del Valle del Roncal y Reino de Navarra, Madrid, Blas de Villanueva, 1711; y una relación sobre la misión de Mojos "Carta al Padre Martín de Jáuregui, Provincial del Perú, sobre el origen de las misiones de Mojos (Nuestra Señora de Loreto, 18 de octubre", en MaurTua, V. M.: Juicio de límites entre el Perú y Bolivia, Madrid, Impr. de Henrich y comp., 1906, 10/2, pp. 1-24).

47 Esta obra ha sido traducida al castellano por BARnADAs, J. M.: Breve descripción de las reducciones de los Mojos, Cochabamba, Historia Boliviana, 1985. 
mos a aquellos, destaca la Relación Historial de Indios chiquitos, del jesuita Patricio Fernández, editada en Madrid, en 1726, y que fue pronto publicada en alemán, latín e italiano. El fracaso ante otros grupos como los chiriguanos llevaría a los jesuitas a no consagrarles ninguna obra importante más allá de algunos párrafos en las historias generales y en las cartas anuas, quedando sólo algún testimonio de misioneros franciscanos que les reemplazaron en esta misión ${ }^{48}$.

Las entradas en todos estos territorios nunca fueron fáciles. A las dificultades que implicaba la propia geografía había que sumar que en la mayoría de ocasiones se requiriera escolta de soldados españoles o de guerreros de caciques aliados ${ }^{49}$. En su mayoría eran años de inversión en visitas periódicas de aldeas aisladas y poco pobladas, antes de conseguir que indios de etnias diferentes aceptasen una residencia común. En ocasiones ni eso aseguraba la continuidad de éstas por las mudanzas y violencias de las relaciones entre los propios grupos indígenas. Las posibilidades de éxito requerían en primer lugar ganarse la confianza de los jefes con todo tipo de regalos y disipar los temores indígenas sobre las verdaderas intenciones de los misioneros, temerosos aquéllos de que los padres fuesen la punta de lanza de su esclavización. El jesuita Julián de Aller, en el informe que envió al provincial de Lima en 1668 sobre su entrada en las tierras de los mojos, advertía que los indios desconfiaban de él por "una hablilla" que hacían los más viejos en la que se decía que los misioneros iban "a engañar y descuidar las gentes, para que después con el seguro entrasen los españoles y se apoderasen de ellos". Por ello, "hubo Cacique que lo creyó tan de veras, que de hecho envió a su pueblo para que los suyos se retirasen al monte y no nos recibiesen, pero Nuestro Señor lo dispuso mejor" ${ }^{50}$. No era pues de extrañar que los misioneros recomendasen que para pacificar nuevas naciones no entrasen los religiosos con "españoles de repente, ni en armadas a sus tierras, sino que mediante lenguas [traductores], o otros indios sus amigos, se comuniquen y vayan poco a poco (...) hasta que pierdan [los indios] el miedo que les tienen y con que se assustan", y que, en todo caso, haciendo entrada deban de ser estas calculadas para apresar algunos indios que "haciéndose ladinos en nuestro poder, sirvan después en el tratar, hablar y apaciguar a su Parientes" ${ }^{51}$. Los jesuitas eran plenamente conscientes del papel de mediadores que los colonos fronterizos les otorgaban para resolver los conflictos con los indios hostiles a la presencia europea.

Todo ello contribuía a la lentitud en el progreso en los bautismos, si bien los jesuitas, a diferencia de otras órdenes religiosas misionales, eran más partidarios de la constancia en el tiempo para obtener una conversión sincera a los efectos efímeros de una campaña epidérmica y multitudinaria. Sabían que su objetivo final era el transmitir modelos políticos y sociales europeos a las poblaciones conquistadas, lo que a la larga conllevaba la sedentarización de la misión. Su estrategia conlleva una planificación a largo plazo, razón por la que priorizaban la catequización de los

\footnotetext{
48 SAignes, T.: "Las sociedades del Oriente boliviano según las fuentes misioneras recientemente edificadas", en Simposio sobre las misiones jesuitas en Bolivia, op.cit. (nota 35), p. 50.

49 Altamirano, op. cit. (nota 1), p. 61.

50 Barnadas, op. cit. (nota 44), p. 32. BNE, Ms. 13.530 (nota 28), fol. 38

51 Ibidem, fol. 135.
} 
más pequeños a la de los adultos de las aldeas ${ }^{52}$. Además, siempre era difícil lograr que los indios comprendieran los principios cristianos que se les enseñaba, aunque los misioneros se valiesen de traductores nativos ${ }^{53}$. También, algunos indios amazónicos desconfiaban de este sacramento y lo ponían en relación con la difusión de las violentas epidemias que se propagaban ${ }^{54}$, o con la intención de los misioneros de registrar en sus libros a los neófitos bautizados para en un futuro repartirlos entre los españoles como esclavos ${ }^{55}$. Idénticas prevenciones para desanimar a las conversiones expresaban algunos caciques contra el matrimonio cristiano monógamo, que trataba de desterrar su tradición polígama. Por ello, algunos no dudaban en recurrir a subterfugios como el de señalar a sus segundas y terceras esposas como simples criadas de la esposa principal, o bien terminaban por rehuir la reducción, temerosos de perder en ellas a sus mujeres a manos de los padres.

Con todo, más allá de la hostilidad de los indígenas, lo insalubre del clima y del territorio en general, la inadecuada alimentación, la fatiga de atender el apostolado, que tendía inexorablemente a recortar los años de vida de los misioneros, era la sensación de soledad la más terrible adversaria de su fortaleza moral de los misioneros, tal y como lo expresaba el jesuita Francisco de Figueroa en 1661, al referirse a su experiencia entre los mainas, ubicados en la región amazónica actual entre el Ecuador y el Perú,

[...] por que el aver de estar muchos meses, que tal vez passan de seis, por contingentes, que ay, sin ver a otro sacerdote, ni aun a algún español, ni poderse confesar, es de mucha pena (...) Solamente sirbe de consuelo el estar haciendo el negocio de la salvación de essos Pobres: y de Dios, por quien se trabaja; y con quien es menester tener mucha comunicación para poder passar. Su divina Majestad acude como Padre al alivio de quien por su amor se destierra a tales soledades. Sobre todo, no es poco el tormento, de lidiar con troncos animados y hombres irracionales. Tales son comúnmente hablando, los indios que se crían en estos bosques, porque parecen salbajes, hombres silvestres, brutos con figura humana y hombres con acciones de brutos ${ }^{56}$.

La actitud de los misioneros no sólo se basaba en lo que establecía las normas de las Constituciones. La formación de los jóvenes jesuitas incluía además la lectura de los Ejercicios Espirituales y otros escritos de Ignacio de Loyola, con enseñanzas profundamente espirituales e incluso místicas que ayudarían a sobrellevar aquella inmensa sensación de desencuentro que podían experimentar los misioneros. En ellos, practicados en las horas de retiro en la soledad de sus destinos misionales, debieron, como apuntan las narraciones, encontrar la fuerza que les permitiría actuar como sol-

52 Ibidem, p. 58.

53 Rivero insistía en que era difícil fiarse de los interpretes "en materias de fe, pues en semejantes ocasiones, como lo tengo experimentado, no interpretan aquello que el Padre dice, sino lo que les parece mejor, venga o no venga al intento, sobre el misterio de que se habla, y todo se vuelve confusión, y quedan los catecúmenos, después de la instrucción por intérprete, tan incapaces para el bautismo como antes y, quizás, llenos de errores contrarios a nuestra fe, por ignorancia de su intérprete", RIVERO, op. cit. (nota 10), p. 57.

54 Altamirano, op. cit. (nota 1) p. 152.

55 BNE, Ms. 13.530 (nota 28), fol. 38.

56 Ibidem, fols. 163-169. 
dados de una Compañía al servicio de Dios y una forma distinta de "entender y practicar la santidad, hecha de heroísmos y en línea siempre recta hacia Dios”, sorteando la melancolía que ponía en riesgo la firmeza de sus vocaciones ${ }^{57}$.

\section{LA LITERATURA MISIONAL}

Para evitar aquellos temores era necesario previamente mostrar a los futuros misioneros qué empresas les aguardaban. El jesuita Juan Rivero insistía en este objetivo final de su narración:

Piensan los que están en la Europa, y se hallan movidos a pasar a las Indias para convertir infieles, que lo mismo es salir del mar y pisar la arena de estas playas, que hallar a los primeros pasos ciudades habitadas por gentiles o pueblos muy numerosos como en China y en el Japón; suben luego al espacio imaginario, y con un Cristo en la mano y con el don de lenguas empiezan a hacer prodigios, convirtiendo en muy pocos días y bautizando innumerables gentes. De aquí nace que cuando pasan a estos sitios y ven las dificultades, y que para formar un pueblo se necesita de una constancia invencible de muchos años; que es necesario aprender su lengua a costa de mucho estudio, que hay que sacar a los indios de las montañas y entrar a cazarlos como a fieras; que es preciso vestirlos y mantenerlos al principio, hasta que formen sus labranzas; que ya se huyen unos y se revelan otros; y que apenas tienen de racionales la figura exterior, caen de ánimo, suspiran por la Europa, su patria, o empiezan a poner los ojos en otras empresas como las de China y el Japón, como si allá no hubiera dificultades que vencer, y tal vez mayores que las que se presentan aquí. Pues para desengaño de estos tales, y para que cuando pasen a esta América vengan desengañados en orden a las sobredichas dificultades, quiero poner por menudo los pasos y lances que ha constado fundar este pueblo $[\ldots]^{58}$.

La literatura misional debía cumplir las funciones de un manual de oficio, de un taller en el que se formasen los futuros "[...] Apóstoles, que imitando a los doce primeros en el ministerio y oficio, se emplearan en la conversión del gentilismo como lo hicieron aquellos" ${ }^{59}$, alertándoles de los riesgos y de la necesaria prudencia para sortearlos. Pero también cumplía con una doble finalidad. Por un lado, su cometido principal era dar fe de sus labores evangélicas emprendidas en un determinado espacio geográfico, distinguiéndolas de las del resto de órdenes misioneras, siendo narradas por los propios jesuitas, convertidos en el corazón y ojos de sus propias historias. Tenían pues, una finalidad propagandística, entusiasta a la vez que autocomplaciente, que fortaleciera su espíritu corporativo y que sirviera, a su vez, de defensa frente a las críticas de sus rivales y detractores, de las cuales con frecuencia se hacían eco en

57 IGNACIO de Loyola, op. cit (nota 2), p. 68. Como nos ha recordado Lasso Varela, más allá de los objetivos políticos de las entradas de los misioneros y sus buenos deseos civilizatorios de sus reducciones, conviene no "olvidar que el misionero apostólico se guiaba por una vida íntima en Cristo (...), pues de hacerlo las misiones jesuitas se convertirían en hechos históricos que carecerían de un altruismo abstracto y, por lo tanto, sin contenido real". LASSO VARELA, op. cit. (nota 16), p. 450.

58 Rivero, op. cit. (nota 10), p. 350.

59 Ibidem, Dedicatoria, XI. 
sus páginas, no sin cierto tono victimista, recordando uno de los tópicos más recurrentes de la literatura jesuítica: la de orden perseguida pero triunfante ${ }^{60}$. A través del discurso afectivo de su narración, que exaltaba las notas de heroicidad de sus protagonistas y el exotismo de los lugares donde se desarrollaba la acción, se brindaba la ocasión para el despertar de nuevas vocaciones en los refectorios de los colegios de la Compañía, en donde eran leídas o escuchadas con pasión ${ }^{61}$. Pero además, y aunque pueda parecer paradójico, esta literatura misional también transpiraba un cierto tono preventivo hacia los indecisos: al poner en valor la oposición entre los valores del sufrimiento y la humildad elegidos por los misioneros frente a la vida regalada y meritoria en los colegios urbanos, esta literatura también era una advertencia para aquellos que pretendieran el ingreso en la Compañía de Jesús como un medio para alcanzar sus ambiciones personales, recordándoles cual era la primitiva naturaleza fundacional del instituto ${ }^{62}$.

De hecho, sólo una parte modesta de estas obras llegó a ser editada. Fue un género que circuló en su tiempo más en forma manuscrita que impresa ${ }^{63}$, a pesar de que tenemos constancia de su buena recepción entre el público europeo ${ }^{64}$. En parte pudo deberse a que fuera concebido para el consumo interno de la Compañía y no tanto para un público más general y curioso, sobre todo cuando se tocaban extensamente temas delicados como la idolatría, entendida como obra de inspiración demoníaca. También hay indicios de que el poco entusiasmo por su publicación fuera más bien institucional, ya que si bien algunos de los escritores jesuitas pensaron en su edición, muchos de ellos se vieron luego defraudados, bien porque afectara en sus relatos a personas todavía vivas, bien porque el celo con que exponían los prodigios y vidas virtuosas de muchos de sus protagonistas podía entrar en contradicción con los decretos de 1625 de Urbano VIII sobre la promoción de mártires a la beatificación, lo que siempre motivó una cierta cautela. Al fin y al cabo, circular de forma manuscrita continuó siendo una forma valida de hacerlo y una manera mucho más eficaz de evadir la censura religiosa, moral y política ${ }^{65}$. No obstante, esta literatura nunca renunció a su carácter lisonjero. Algunas de las obras editadas lo fueron en provecho

\footnotetext{
60 Ibidem, pp. 62-67.

61 Tal y como recordaba el padre Cipriano Barace, misionero en Mojos, cuando como colegial en el colegio de Lima escuchó el relato de la muerte del jesuita romano Nicolás Mascardi por los indios bárbaros de Chile, o la del también jesuita Diego Luis de Sanvítores, apóstol de las Marianas. Altamirano, op. cit. (nota 1), pp. 132-133. La lectura de estos textos o de las cartas remitidas por misioneros desde las Indias sirvieron como fuerte reclamo para despertar nuevas vocaciones, tal y como señala el estudio de las Indipetae de la provincia bética. Rico Callado, F. L.: "El 'Deseo de las Indias' entre los jesuitas de la provincia de la bética de la Compañía de Jesús en los siglos XVI y XVII", en Soto ArtuÑedo, W. (ed): Los jesuitas en Andalucía. Estudios conmemorativos del 450 aniversario de la fundación de la provincia, Granada, Universidad de Granada, 2007, pp. 563-564.

62 Maldavsky, op. cit. (nota 20), pp. 342-344.

63 Bouza, F.: Corre manuscrito. Una historia cultural del Siglo de Oro, Madrid, Marcial Pons, 2001, p. 18. Muchas obras no conocerían una edición impresa hasta el siglo XIX, en un momento de nacimiento de las historiografías liberales americanas que buscaban en esta tradición unos precedentes propios.

64 Borja GonzÁlez, G.: "Libros americanos, autores jesuitas y público alemán: la literatura jesuítica americana en el mercado de libros del siglo XVIII", en KoHUt, op. cit. (nota 4), pp. 663-696.

65 Burke, P. y Briggs, A.: De Gutemberg a Internet. Una historia social de los medios de comunicación, Madrid, Taurus, 2002, p. 59.
} 
de protecciones políticas o financieras para las misiones, por lo que siempre convenía dejar constancia en sus páginas de los benefactores que las habían hecho posibles o se realizaban de manera más abierta para mover los afectos de un público más amplio que pudiera ayudar a los intereses de la Compañía ${ }^{66}$. Así, en una breve relación del padre Altamirano que se imprimió en Madrid en 1714, sobre el estado de las misiones en Mojos (previamente impresa en Lima en 1700), podemos leer como se apelaba por igual a la caridad de los particulares como de la Corona para sufragar el costo de los 1000 pesos que costaba llevar cada nuevo misionero de Lima a Mojos ${ }^{67}$.

Sin duda, la literatura misional constituyó un corpus textual coherente y bien articulado dentro del sistema cultural de los jesuitas. Su redacción fue el resultado de la confluencia de una manera de mirar el mundo y de una hábil mezcla de discursos literarios para expresarlo. El saber de los jesuitas se fundamentaba en el dinamismo moderno de tres coordenadas: la herencia del conocimiento aristotélico y de la tradición bíblica cristiana; la orientación humanista de su régimen educativo (Ratio Studiorum); y, por último, sus prácticas institucionales. De la primera procedía su sobrevaloración de la libertad y el libre albedrío y su concepción jerárquica de la naturaleza y de las sociedades, mezclada con una cierta dosis de providencialismo agustiniano que integraba toda obra natural en la que se ubicaba el hombre, como ha señalado Fermín del Pino, en una construcción racional jerarquizada (de lo simple a lo compuesto) y finalista (de servicio de lo inferior a lo superior), concluyendo este edificio natural en el propio Dios ${ }^{68}$. La búsqueda de conocimiento sobre la naturaleza, es decir sobre la Creación, estaba pues legitimada en tanto contribuía al conocimiento de Dios, del propio Creador, o como lo expresaba la Compañía de Jesús en su lema: ad majorem Dei gloriam $^{69}$. Por su parte, del humanismo tomó la Compañía el uso continuado de textos clásicos como ejercicio de retórica y como modelos de vida y sabiduría, favoreciendo su capacidad para elaborar las comparaciones que hicieran comprensibles las nuevas realidades americanas a los europeos de su tiempo. Precisamente la experiencia misional en enclaves geográficos muy diversos fue la que dio a la Compañía de Jesús la posibilidad de ver en directo ejemplos de los que hablaban las fuentes del pasado histórico (Plinio, Herodoto...) y corroborarlas o rebatirlas. Finalmente, la actividad intelectual de los jesuitas se vio beneficiada por la constante circulación institucional de noticias, cartas e informes que sobre la cultura, naturaleza y cosmografía de las regiones en que se asentaban se enviaban a su cabeza en Roma para que desde aquí se redifundieran tanto para satisfacer la curiosidad de maestros y

66 Altamirano, op. cit (nota 1), pág. 81.

67 “Oh! y si cada hombre, para empeñar a Dios en la salvación de su alma, con una limosna bien corta tratase de ganar un alma para Cristo! Si cada señora rescatase una india de la esclavitud del demonio." BARNADAS, op. cit. (nota 43), pp. 66 y 75.

68 Pino Díaz, op. cit. (nota 12), p. 62.

69 Millones FigueroA, L.: "La intelligentsia jesuita y la naturaleza de Nuevo Mundo en el siglo XVII", en Millones Figueroa, L. y Ledezma, D. (eds.): El saber de los jesuitas, historia naturales y el Nuevo Mundo, Madrid, Vervuert-Iberoamericana, 2005, p. 36. EchEvARríA, B.: "La Compañía de Jesús y la primera modernidad de América Latina", en Scumm, P. (ed.), Barrocos y Modernos. Nuevos caminos en la investigación del Barroco iberoamericano, Madrid, Vervuert-Iberoamericana, 1998, p. 54. 
estudiantes de sus colegios por todo el orbe como, de llegar a la imprenta, para deslumbrar y obsequiar a señores poderosos que protegían sus intereses ${ }^{70}$.

Las crónicas misioneras eran parte del corpus textual que circulaba por la red comunicativa jesuita, ocupando un lugar intermedio entre las fuentes primarias de tipo oral o escrito que servían de base a su redacción, y el deseo de que constituyesen una primera elaboración que remitiese a una categoría superior de textos constituidos por las crónicas provinciales, base de la historia universal de la Compañía que se compondría en Roma ${ }^{71}$. En efecto, por su naturaleza inicial manuscrita, la literatura misional jesuita se convirtió en un medio "interactivo", donde también es frecuente encontrar ese tránsito entre lo oral y lo escrito. Al reproducir minuciosamente experiencias propias o testimonios de los misioneros o de personas que estaban al final de la cadena de transmisión de éstos ${ }^{72}$, sus folios reproducían a menudo residuos orales más apropiados al habla que a la escritura, al oído que a la vista. Esto era perfectamente perceptible cuando se reproducían diálogos entre los misioneros y los lenguas que les servían de intérpretes de las culturas que visitaban o cuando, por ejemplo, se reproducían acciones dramáticas vividas por los misioneros, que se enfatizaban más para la declamación que para la lectura en silencio ${ }^{73}$.

Por otro lado, esta literatura bebía de la tradición de diversos géneros literarios muy presentes en el acervo europeo de la época. En cuanto que la movilidad se convertía en un eje central de su estructura narrativa -el recorrido de los misioneros sobre las tierras fronterizas que exploraban y pretendían cristianizar-, ésta se hacía eco de la rica tradición que desde la Edad Media en Occidente se había dedicado a la narración de viajes, y que tuvo su traslado a las crónicas históricas del Nuevo Mundo ${ }^{74}$. Pero no fue la única. De hecho, metabolizó también otros géneros como la Historia natural - enorme fue la influencia en toda esta literatura de la obra del padre Acosta-, las relaciones epistolares -que en ocasiones se insertaba en la narración interrumpiéndola para ratificar la veracidad de lo que los autores explicaban-, las hagiografías y vidas ejemplares -que seguían la estela de los modelos narrativos surgidos a partir del siglo XIII con La leyenda dorada del dominico Jacobo de la Vorágine-; o las novelas de caballería, entre otras ${ }^{75}$. Así, los textos se estructuraban a partir de una serie de ejes

70 Ibidem, p. 28. Harris, S.: "Mapping the Jesuit Science" en O'Malley, J. (ed.): The Jesuits: cultures, sciences, and arts, 1540-1773, Toronto, Toronto University Press, 2006, p. 215.

71 Betrán Moya, J. L.: "La Compañía de Jesús y el mundo del libro impreso en tiempos de Francisco de Borja”, en García Hernán, E. y Ryan, M. P. (eds.): Francisco de Borja y su tiempo, Valencia-Roma, AlbatrosIHSI, 2011, pp. 413-414.

72 Burke, P.: "Del Renacimiento a la Ilustración", en Aurell, J., Balmoceda, C., Burke, P., y Soza, F.: Comprender el pasado. Una historia de la escritura y el pensamiento histórico, Madrid, Akal, 2013, p. 156. SuÑE Blanco, B.: "Documentación primaria y crónicas históricas: efectos de las circunstancias en la versión de los hechos", en Revista Española de Antropología Americana, (2003), p. 183.

73 Fernández, P.: Relación historial de las misiones de indios chiquitos, Madrid, Librería de Victoriano Suárez Editor, 1895, vol. 1, pp. 162-164.

74 López de Mariscal, B.: Relatos y Relaciones de Viaje al Nuevo Mundo en el siglo XVI, Madrid, Polifemo, 2004.

75 Rubial García, A.: La santidad controvertida. Hagiografía y conciencia criolla alrededor de los venerables no canonizados de Nueva España, México, FCE, 1999, p. 31. Asimismo, véanse los sugerentes trabajos incluidos en VITSE, M. (ed.): Homenaje a Henri Guerreiro. La hagiografia entre la historia y literatura en la España de la Edad media y del Siglo de Oro, Madrid, Iberoamericana, 2005. 
comunicativos que tenían la finalidad de proporcionar información geográfica, histórica y etnológica; reunir información estratégica con miras a proporcionar nuevos descubrimientos y nuevas conquistas espirituales; construir, mediante la estrategia discursiva de la descripción, escenarios en los que presentar las características de los lugares recorridos y las costumbres de sus habitantes; y, finalmente, reproducir, mediante la estrategia discursiva de la narración, las aventuras, vicisitudes y hazañas de los protagonistas. En todo caso, eran un conjunto de motivaciones básicas construidas a partir de una idea central: dar cuanta de lo extraño, lo inusitado, lo excepcional ${ }^{76}$.

La geografía solía ser el primero de los saberes presentados. Los narradores mostraban su asombro por las características de los espacios inmensos que iban encontrando a su paso: los ríos de enormes dimensiones, en ocasiones caudalosos e imposibles de navegar, las montañas elevadas, los desfiladeros y los pasos difíciles, la carencia de caminos que indicaban lugares nunca antes transitados, eran algunos de los elementos de la Naturaleza del Nuevo Mundo que los maravillaban. Un mundo que les podía, por sus excelencias y novedades, recordar las maravillas del Edén, pero que les resultaba difícil de describir en muchas ocasiones. Por ello, cuando se trataba de observar la naturaleza, por lo general encontramos en estos relatos una tendencia a describir las plantas y los animales inusitados a partir de referentes conocidos, conciliando así la capacidad de asombro y la necesidad de racionalizar aquello que se califica de maravilloso, lo que no excluía, en caso de necesidad, la adopción del vocabulario indígena para definir lo nuevo ${ }^{77}$. El asombro frente a la naturaleza implicaba también la observación del entorno y la necesidad de reflexionar sobre la capacidad de producción de las tierras misionadas. A la bondad alimenticia de la naturaleza para sus gentes ${ }^{78}$, los misioneros siempre insistían en las posibilidades de explotación fértil de aquella naturaleza con la introducción de cultivos o ganados que, como afirmaba Altamirano, se multiplicaban en ella "mucho más que en Europa"79. La capacidad de dominar una naturaleza indómita era un derecho que el hombre poseía a partir de la donación que de ella se le concediera en el Génesis y por tanto su dominación se convertía en un instrumento fundamental para la civilización de sus gentes ${ }^{80}$.

No obstante, el misionero jesuita pertenecía al espacio de la civilización. Por eso, a medida que transcurría su viaje y se iba alejando de ésta, se internaba en diferentes territorios que constituían paulatinamente el ámbito del otro, del que era diferente, del hombre salvaje. La descripción de la naturaleza en que operaba entonces cambiaba de registro hasta convertirse en un pequeño infierno plagado de torturas más propias de la imaginación de Dante, con fieras de todo tipo, enjambres de molestos

76 Baraibar, A.: "La Naturaleza en el discurso indiano: la construcción de un espacio de experiencia americano", en CAStany, B. (ed.): Tierras prometidas. De la colonia a la independencia, Bellaterra (Barcelona), Universidad Autónoma de Barcelona, 2011, pp. 9-30.

77 Rivero, op. cit. (nota 10), pp. 1-15.

78 "De todos estos frutos y otros innumerables, ha provisto Dios a estas tierras, supliendo con su variedad y multitud la falta de capacidad y aplicación al trabajo que tienen los naturales. Con ellos mantiene su Providencia el inmenso gentío que anda vagando en tropas por esos campos y montañas...", ibidem, p. 6.

79 Altamirano, op. cit. (nota 1), p. 87.

80 "Tenía el Padre Dionisio a su cuenta las doctrinas de Pauto, distante como un día de camino de los Guagibos á Chiricoas; pasó a visitarlos, y les repartió hachas y otras herramientas, y procuró inducirlos a hacer labranzas, para que en eso sus naturales vagamundos echasen raíces", Rivero, op. cit. (nota 10), p. 150. 
mosquitos zancudos, "unos grandes y otros pequeños, pero crueles todos" 81 , "no menos molestos al oído que sensibles al tacto", o de "[...] culebras y víboras venenosas que se entran por las casas y trepan a los techos" $" 82$.

Pero lo que más atormentaba a nuestros jesuitas eran las bárbaras costumbres de aquellas gentes: sus cultos a dioses de la naturaleza ${ }^{83}$; su poligamia $^{84}$; la practica cruel del infanticidio ("nada de esto causava grave horror como la abominable costumbre de sepultar vivos los propios hijos con bien leves causas"), que hacía exclamar a Altamirano que "hasta aquí puede llegar la barbaridad que ni aún en los brutos por naturaleza amantes de sus hijos se halla cosa semejante" 85 . Culminaba esta imagen de barbarie indígena la carencia de reglas y organización política, que el jesuita parece querer poner en relación con el marco físico:

En este pues ardiente clima comenzaba el demonio a abrazar a estos infieles, en aquellos vestidos con paños apacentaba sus desnudas racionales bestias. Y estas espesas montañas ocultaban montaraces estos hombres brutos, sin gobierno, sin ley, sin política y los más sin Dios [...]. No tenían gobierno político ni dogma racional, ni señor. El que más recio hablaba y menos mal discurría era el más estimado y temido. Y siempre los más valientes eran los más respetados. Gente en fin sin cabeza, sin premio a la virtud, sin castigo al vicio. Bien fue menester que Dios les diese legislador en nuestro Monarca, para que supiesen que eran hombres ${ }^{86}$.

Mostrar la ausencia de toda soberanía sobre aquellas tierras amazónicas era tanto como legitimar la dominación del príncipe español y la obra de conversión cristiana. Es indudable que muchas descripciones sobre las costumbres de los indígenas que contiene la literatura misional estaban influenciadas por la obra de José de Acosta, quien avanzó la idea de que la primera tarea del misionero era conocer las creencias de los indios para poder combatirlas y reemplazar la espiritualidad nativa con la fe cristiana. Al menos este interés de los jesuitas por la cultura indígena reflejaba también la educación y la filosofía tomista de los ignacianos, que afirmaba que todos los hombres -incluidos los indios-eran seres racionales, con algún conocimiento de Dios que hubiera surgido de manera natural o inducida por una predicación arcaica del evangelio antes de la llegada de los mismos españoles ${ }^{87}$. Las crónicas misioneras

81 Ibidem, p. 43.

82 Altamirano, op. cit (nota 1), p. 24.

83 "Adoraban en cada pueblo muchos [falsos dioses], unos particulares de ellos, otros comunes a todos, unos casados, otros solteros, cada uno con diferente empleo y ministerio; cual presidente del agua y sus peces; cual de las nubes y rayos; otros de los sembrados; otros de la guerra y otros de los tigres. Y estos últimos eran los que tenían más culto exterior, por el gran terror de aquellas fieras de que abunda aquella tierra, de suerte que son muchos los indios que perecen en sus garras; y al que se libra de sus uñas y voracidad, le miraban como consagrado con la protección del dios de los tigres", ibidem, p. 26.

84 Ibidem, p. 28. Sobre la que, con una visión antropológica moderna apunta que atiende más que a la lascivia de los hombres a la necesidad de tener el mayor número de mujeres que trabajen ("Bien es verdad que habían pocos que tuviesen muchas mujeres, más no por virtud sino por necesidad”), ibidem, p. 44.

85 Ibidem, p. 29.

86 Ibidem, pp. 43-44.

87 RefF, D. T.: "La representación de la cultura indígena en el discurso jesuita del siglo XVII", en Congreso Internacional de Historia, op. cit. (nota 2), p. 309. Así, Figueroa respecto de los mainas dice "Todas las naciones que hasta ahora se han tratado, tienen conocimiento de Dios, y vocablo con que en cada idioma lo 
jesuitas peruanas estuvieron entre las que más propagaron el mito de una predicación antiquísima en aquellas tierras llevada a cabo por el apóstol santo Tomás, que habría anunciado la llegada de una orden religiosa (la de san Ignacio), dedicada a la conversión de los infieles ${ }^{88}$. Para testimoniar la obtención de ese objetivo, no era infrecuente que los autores recurrieran a recursos narrativos en que se fingieran diálogos con los indígenas en los que el misionero hablaba de sus propias creencias, presentándolas como las únicas aceptables para alcanzar la salvación, urgiendo a los indios a abrazar la nueva religión y abandonar sus antiguas creencias ${ }^{89}$.

Sin embargo, la efectividad de la conversión estribaba tanto en la perseverancia de la acción colectiva -la desplegada en la praxis catequética de las misiones sobre niños y adultos reunidos bajo la enseñanza del misionero en torno a la fábrica de la iglesia-, como en la más sutil, practicada sobre los individuos a través de la aceptación obligada del sacramento de la confesión: era aquí donde los misioneros conseguían imponer el concepto cristiano de la persona, la noción de un yo autónomo y responsable, pecador y redimido, rompiendo la representación heredada que encerraba al indio dentro de una urdimbre de dependencias múltiples que sólo le dotaban existencia en relación con sus dioses, los ancestros o la comunidad. La clave del éxito estaba en lograr que los nuevos conversos interiorizaran una manera inédita de pensar su ser individual y su relación consigo mismos ${ }^{90}$.

El salvajismo que mostraban los indios no dejaba duda de la obligación moral de convertirlos. La dicotomía entre "civilización" y barbarie se estableció así como un recurso discursivo imprescindible en la literatura misional para poder discernir la alteridad cultural. La aparente incapacidad europea para asimilar la diferencia radical del Nuevo Mundo, hizo inevitable la tendencia a domesticar tales diferencias según patrones culturales preestablecidos. Esto explica el frecuente recurso a la comparación entre las experiencias vividas y los diferentes episodios de la historia clásica $\mathrm{o}$ de la Biblia que aparecen con frecuencia en sus páginas. Así, por ejemplo, Rivero nos habla de las Amazonas como pueblo que se sabía que vivía entre el rio Meta y el Orinoco -según sabía por la relación de las misiones que le había llegado del pa-

nombran; llamándolo también Nuestro Padre y Nuestro Abuelo. Y dicen que creó el Cielo, la tierra, hombres y demás cosas y que criando las comidas, para sus hijos, que son los hombres, se fue la Cielo. Esto dicen, ya de una, ya de otra manera, mezclando varios herrores...”, BNE, Ms. 13.530 (nota 28), fol. 172. La misma impresión refiere el padre Julián Aller en su primera entrada en tierras mojas, de cuyos habitantes dice no tener "rastro de idolatrías ni adoración alguna; conocen a Dios y confiesan su divinidad; a Dios le llaman Maymona, que según frase de su lengua, vale "el que lo mira". BARNADAS, op. cit. (nota 44) p. 37.

88 Así lo refiere Figueroa, "Por lo dicho, se puede colegir que tuvieron alguna predicación, antiguamente, y noticia de Dios hecho Hombre, y se confirma, con lo que tenían los Reberos, quienes decían que en tiempos antiguos Dios se hiço Hombre, y les enseñó allá muy abajo deste Río Marañón. Puede ser alguna noticia, que les quedasse y diesse, alguno de los gloriosos Apóstoles Santo Tomás o San Bartholomé, de Christo nuestro Señor, en las partes del Brasil, Paraguay, o Boca deste Río, de donde estas Naciones debieron irse dividiendo, y subiéndose a estas de arriba", BNE, Ms. 13.530 (nota 28) fol. 174. Idéntico discurso en Altamirano, op. cit (nota 1), p. 11; Rivero, op. cit. (nota 10), p. 109. Sobre la relación de los jesuitas con la extensión de este mito, Sanz Camañes, P.: Las ciudades en la América Hispana, Madrid, Sílex, 2004, pp. 89-90.

89 BARnADAS, op. cit. (nota 44), p. 35.

90 El padre Aller recuerda la recuperación de una vieja india a la que catequizó en su lecho de muerte, haciéndole "actos de fe, de esperanza, de amor y de contrición”, de lo que luego milagrosamente una vez convertida, sanó. Ibidem, p. 35. 
dre Neira- formado por "mujeres tan varoniles y guerreras, que no solo mantienen guerras contra otras naciones de menor espíritu, como son los Achaguas, sino con las naciones más carniceras, como son los Cáribes", circunstancia que aprovechaba para relatar su pasado mítico ${ }^{91}$.

Así, a través de un lenguaje que remontaba a sitios comunes del entendimiento de lo exótico, la naturaleza del indio americano se hacia comprensible para el público europeo ${ }^{92}$. Ciertamente, no todo era falso en los estereotipos, pero las exageraciones y las omisiones seguían una lógica clara: domesticar la diferencia, bien fuera a base de falsas analogías con lo ya conocido, bien fuera a base de simplificaciones que crearan una imagen artificial de lo culturalmente diverso. Indudablemente, el análisis de las analogías con el mundo del paganismo funcionó como matriz interpretativa perfecta para la percepción de las religiones indígenas, y para establecer, a la vez, un claro distanciamiento de aquellas. Altamirano decía de los mojos que "tenían muchos errores semejantes a las fábulas de los antiguos gentiles" ${ }^{93}$. De esta manera, las crónicas de los evangelizadores jesuitas describían sistemáticamente una imagen fija de conductas consideradas pecaminosas -la idolatría, los sacrificios cruentos, la antropofagia y las prácticas sexuales "contra natura", la promiscuidad, la carencia de reglas de parentesco-, como estereotipo reprobatorio que demostraba la carencia de moral de los indios y cuyas raíces intelectuales se hundían en la Antigüedad, desde la que la teología cristiana las había trasladado hasta los relatos de la evangelización del indio americano ${ }^{94}$.

Junto a ello, la violencia también constituía otro de los signos de la identidad atribuidos a los indios amazónicos. En sí, las etnias no constituían conjuntos políticos unificados: éstas se dividían en varias unidades locales independientes. En este sistema fragmentado, la guerra desempeñaba un papel esencial para mantener la autonomía local y alentar la igualdad interna. Esta igualdad, aun si coexistía con una cierta jerarquía de prestigio (lideres, chamanes, guerreros y, a veces, esclavos) explicaba la intervención de todos los sectores de la sociedad en la toma de decisiones ${ }^{95}$. Las asambleas eran tumultuosas y, en caso de divergencias internas irremisibles, el grupo podía escindirse. Las oportunidades de recelo para con los otros grupos vecinos, y por ende de conflicto, no hacían falta: disputas de botín o de mujeres, sospechas de maleficio (ninguna muerte era natural), y sobre todo herencia de obligaciones de venganzas, que podían alimentar ciclos durante varias generaciones y que con facili-

\footnotetext{
91 Ibidem, p. 17.

92 Rubiès, J. P.: "Imagen mental e imagen artística en la representación de los pueblos no europeos. Salvajes y civilizados, 1500-1650", en PAlos, J. L. y CARrió-Invernizzi, D.: La historia imaginada. Construcciones visuales del pasado en la Edad Moderna, Madrid, Centro de Estudios Europa Hispánica, 2008, pp. 333-334.

93 Altamirano, op. cit. (nota 1), p. 28.

94 Pastor, M.: “Del 'estereotipo del pagano’ al 'estereotipo del indio'. Los textos cristianos en la interpretación del nuevo Mundo", en Iberoramericana, XI, 43 (2011), pp. 10 y ss. En términos generales la actitud de los misioneros hacia las creencias de los naturales fue de extrañamiento y repudio. Pero es cierto que muchas de estas actitudes se suavizarían con el tiempo, lo que muestra que en esta literatura es posible vislumbrar una creciente aceptación del relativismo cultural. Es el caso de la Descripción de los Moxos que están a cargo de la Compañia de Jesús en la provincia del Perú, redactada en 1754 por un jesuita anónimo. BARNADAS, op. cit. (nota 44) pp. 98 y ss.

95 Altamirano, op. cit. (nota 1), p. 108.
} 
dad estallaban con motivo de los frecuentes encuentros festivos en los que se ingería abundante chicha hasta acabar en la embriaguez de todos sus participantes ${ }^{96}$, lo que explicaba los frecuentes episodios de violencia que protagonizaban los indios y que obligaba a los misioneros a actuar, como lo había hecho en la vieja Europa, como "ángeles de paz" que evitaran las confrontaciones ${ }^{97}$.

Pero además esa violencia se caracterizaba por su extremada crueldad, como la que describía Rivero al referir la atrocidad del cacique Chacuamare, que "cubrió de cadáveres de Achaguas las arenas del Meta, haciendo que corriese sus espumas enrojecidas con sangre de inocentes" 98 . La ferocidad de este personaje quedaba reflejada en la violencia sin límites desplegada contra la inocencia contrapuesta de los niños de aquella tribu:

Son indecibles las crueldades que ejecutó en esa gente, pues no satisfecho con destrozar a los grandes, llevaba su crueldad contra los niños, a quienes cogía vivos, y con inhumana fiereza, a unos picaba los ojos con agujas, a otros los metía en unos pilones o morteros y los hacía majar y moler como si fuera trigo, a otros los estacaba con agudos palos, atravesándoles el cuerpo hasta romperles las entrañas ${ }^{99}$.

Pero en todo caso, la violencia no era monopolio de los indios. También la mostraban de manera terrible los propios conquistadores españoles. A pesar de haber pasado más de ciento veinte años cuando escribía Rivero su historia, permanecían en la memoria de los indios achagua los estragos de despiadados capitanes como Alonso Jiménez o Lázaro Cruz, que habían aprovechado las primeras reducciones de los misioneros entrados en sus tierras para apresarlos y darles cuartel, hasta tal punto que "quedó tan horrorizada esta Nación con el crimen referido, que ya no podía mirar a los españoles como a hombres sino como a monstruos del abismo nacidos para su mal y para destrucción del mundo" " ${ }^{100}$. Era aquí, donde la dicotomía bárbaro/ civilizado se volvía más problemática a la hora de repartir los roles entre europeos e indios, apareciendo los misioneros como ovejas inocentes y desarmadas en el centro de aquella turbulenta crueldad ${ }^{101}$. En las memorias misionales de los jesuitas peruanos persistió siempre un cierto espíritu de denuncia lascasiana ${ }^{102}$. Al referirse a las entradas armadas y a la actuación de los encomenderos sobre los mainas, Figueroa era muy explícito al respecto:

Haciánse algunas injusticias graves a los indios nacidas de ignorancia o malicia como era servirse de ellos como de esclavos, echándoles cargas y servicios que no

\footnotetext{
96 Como decía Rivero, “el beber era su vivir, toda su felicidad y su gloria”. Rivero, op. cit. (nota 10), p. 107.

97 Ibidem, p. 167.

98 Ibidem, p. 38.

99 Ibidem, p. 40.

100 Ibidem, p. 24.

101 "ovejas sin alguna arma entre hambrientos y feroces lobos irritados por rabiosos Demonios", Altamirano, op. cit. (nota 1), p. 98.

102 Galvez Peña, C. M.: "Imaginar la conquista del Perú: historia y utopía en la crónica del P. Oliva, S. I.", en Pino Diaz, F. Del (coord.): Dos mundos, dos culturas. O de la historia (natural y moral) entre España y el Perú, Madrid, Iberoamericana, 2004, pp. 257 y ss.
} 
devian por sus tassas de tributos; quitavan a los indios sus mugeres, si eran gentiles, quando pertenecían a distintos repartimientos diciendo no avía matrimonio entre gentiles. Sacábase mucha gente de varias Provincias yendo en Armada, cogiéndola y trayéndola en gruesas tropas, que repartían entre soldados y vecinos, que son las que llaman pieças, de que se ocassionaban en essas desdichadas gentes, lastimosas mortandades, pues dentro de pocos días, apenas quedavan vivos la décima parte. Estas y otras insolencias avía que los llevava a su perdición ${ }^{103}$.

Añadía Figueroa a esta negativa relación de los españoles sobre los indios, la coincidencia que se establecía entre su contacto y la difusión de terribles epidemias, cuya descripción recordaba los clichés literarios habituales, incluidos la de la voluntad divina del envío de tales plagas como castigo a la inmoralidad de los indígenas. Aunque pudiera parecer rocambolesco, el posibilismo jesuita de Figueroa convertía este providencialismo en un beneficio para la conversión final de los indios, pues salvándose los menos resultaría más fácil la de los que sobrevivieran.

Últimamente es muy probable, que no es tanto castigo de malos como misericordia para muchos, atendiendo la divina piedad a que en la sucesión de tiempos se salbarán más siendo pocos que abrá con la ley de Christo Nuestro Señor, que se salbarían siendo muchos que conserben sus barbaridades, permaneciendo en ellas y llebándose tras de sí a los pocos; y volviéndose contra la doctrina, y contra quien los enseña, biendose con fuerças y poderosos para intentar alzamientos y destruir a los españoles, y a todo lo que es nombre de cristianos ${ }^{104}$.

Los grandes peligros, lo maravilloso, junto a lo monstruoso y lo demoniaco se convirtieron también en tópicos estratégicos de la literatura misional, reflejo a su vez de una teología jesuita gustosa de lo maniqueo y lo escatológico ${ }^{105}$. El territorio fronterizo se convertía así en una combinación de tinieblas y de vacío. Las condiciones de vida hacían pensar en la ausencia de todo lo que manifestaba la mano divina. Si no se percibía ésta, entonces el reino con el que se compartía la demarcación debería estar encabezado por el demonio ${ }^{106}$. Fue contra él, y no contra los indígenas, hacia donde se orientó la ofensiva de los misioneros. La presencia física de Satanás fue más bien episódica ${ }^{107}$, y los naturales, incluidos sus hechiceros, no fueron considera-

\footnotetext{
103 BNE, Ms. 13.530 (nota 28), fol. 7.

104 Ibidem, fols. 136-137.

105 ECHEVARría, op. cit. (nota 69), p. 54.

106 Sobre la importancia de la figura del demonio en la literatura misional religiosa americana véase la obra de Cañizares Esguerra, J.: Católicos y puritanos en la colonización de América, Madrid, Marcial Pons, 2008.

107 Existe algún episodio en que se pretende asociar por parte de los misioneros la analogía entre algunos cultos indígenas y la presencia real del diablo, como es el caso de Rivero cuando explica que entre los tunebos y tames había una gran laguna donde el demonio se les aparecía en forma de gran serpiente de la que como un Oráculo, recibían respuestas y consejos los indios. Ante la entrada inminente de los jesuitas en los Llanos, la serpiente les habló diciendo "Que pronto vendrían a sus tierras unos hombres blancos con ropas largas y negras [los jesuitas], y venían a enseñarles cosas diferentes y contrarias a las que ella les había dicho siempre; que no les creyesen, porque eran embusteros y engañadores; y que aunque ella no podría hacer nada contra los de las ropas largas, ni les podía estorbar que viniesen, que no se desconsolasen ni dejasen de recurrir a ella en sus necesidades, que les ayudaría como hasta allí", dicho lo cual "se zambulló la sierpe entre las olas, dando silbos horribles", RIVERo, op. cit (nota 10), p. 98.
} 
dos la personificación del demonio sino simplemente los que le estaban sometidos. Ciertamente, el demonio siempre trataba de poner todos los obstáculos posibles a los avances de la conversión de los misioneros, empezando por la propia diversidad de lenguas, que convertía la región de la Amazonia, como expresaba el jesuita austriaco Pablo Maroni, en una auténtica "Babel bíblica"108.

Pero era en la violencia de los indígenas contra los padres cuando alcanzaba su máximo clímax la narración misional. Inspirados en el género hagiográfico, que por siglos proveyó a los jóvenes europeos de modelos a emular, su influencia en estos textos se aprecia en la preocupación de sus autores por recordar la variedad de desafíos que los misioneros encontraban (y vencían): los encuentros con sanguinarios caciques y diabólicos hechiceros indígenas eran de la misma naturaleza de la que habían afrontado y vencido los santos durante la Edad Media en Europa. Las grandes hazañas fueron una constante en este tipo de relatos, ya se triunfase o se fracase en ellas. En algunos casos resultaban espectaculares, como el ejemplo que nos muestra el relato que el padre Rivero escribió de la huida protagonizada en 1669 por el padre Juan Ortiz con los indios de su reducción mientras les perseguían por la selva los indios caribes durante 55 días ${ }^{109}$; o el lance similar del padre Julián Vergara, quien en 1684 deambuló durante 105 días hasta alcanzar a un refugio seguro en Casane ${ }^{110}$. De la pluma de Rivero, la narración dramática de estos episodios se convertían en auténticas analogías fácilmente entendibles para el lector europeo receptor del viaje bíblico de Moisés, cuando éste había guiado en parecidas circunstancias al pueblo de Israel en su marcha de Egipto hacia su salvación.

Ciertamente, en todos aquellos episodios el misionero salía venturoso del peligro gracias a la voluntad divina, lo que remarcaba el providencialismo como otro de los elementos característicos del género misional. La invocación constante a Dios, y el agradecimiento al salir airosos de peligros y traiciones hacía que la narración de tantos hechos admirables resultase creíble para un público receptor que, en el Barroco, aceptaba lo maravilloso como parte integrante de su marco cultural.

El sacrificio personal del misionero, incluso con su vida dada en martirio, devenía finalmente su triunfo civilizatorio sobre la gentilidad, sobre el demonio, al que los jesuitas veían detrás finalmente de cada acción de los indios. Numerosos son los ejemplos de muerte violenta de los misioneros jesuitas en las obras estudiadas. Pero incluso, tras su muerte sus restos, convertidos en preciadas reliquias, seguían siendo útiles. Así, la recuperación de los huesos del padre Cipriano Barace, al que los indios baures habían dado muerte en 1708, fue recibido con idéntico alborozo por los misioneros e indios de su reducción como un auténtico triunfo:

Hallaronse pues las preciosas reliquias en el mismo lugar donde lo martirizaron con extraordinario consuelo de nuestros Misioneros y regocijo de los indios que alegres no menos que los vencedores con los despojos de su triunfo, con solemne y numeroso concurso le trasladaron a su reducción antigua que había fundado dedicada a la Santísima Trinidad, donde le recibieron sus hijos en Cristo, a quien habían nacido por medio

\footnotetext{
108 Maroni, op. cit. (nota 29), p. 167.

109 Rivero, op. cit. (nota 10), pp. 230-234.

110 Ibidem, p. 259.
} 
de la conversión y bautismo que habían recibido del difunto, cuya invención celebraban con instrumentos músicos, danzas y arcos triunfales formados con variedad de flores y plumas vistosas, aunque los Padres celebraron con las exequias acostumbradas por la Santa Iglesia para los difuntos y dando al Señor las debidas gracias por el triunfo que se había dignado conceder a su siervo, de que esperaban la conversión de toda la numerosa nación de los Baures, como se iba experimentando ${ }^{111}$.

\section{CONCLUSIÓN}

Aunque parciales, las crónicas misionales jesuitas nos aportan ricas informaciones de la vida religiosa, social y política en la colonia, así como valiosos retratos etnográficos de las poblaciones indígenas en las que éstos misionaban. En el caso del ejemplo peruano son además un valioso testimonio del impulso misional que conoció los márgenes amazónicos del virreinato durante la segunda mitad del Seiscientos, dando un rasgo de identidad propio a las nuevas provincias jesuitas que fueron desgajándose de la primitiva provincia peruana.

El análisis de este tipo de documentos debe tener presente no solo sus componentes históricos, sino también los literarios y religiosos. Su narrativa constituyó un pilar esencial para transitar la distancia de lo maravilloso a lo comprensible, mostrando la convergencia entre el conocimiento heredado de la antigüedad del que eran portadores los misioneros y la necesidad de dar cuenta de los espacios recién encontrados y de los pobladores hasta entonces desconocidos. Del encuentro de ambas, los jesuitas construirán una nueva actitud frente al mundo y frente al conocimiento, en que darán un notable valor a la experiencia ${ }^{112}$.

La asimilación de aquellos ambientes exóticos y de las nuevas categorías humanas conducirá a su domesticación y hará a la larga su existencia menos perturbadora. Los jesuitas tuvieron un papel protagonista en este proceso en el mundo americano. $\mathrm{O}$ al menos así se autorrepresentaron. Tradicionalmente es a Fr. Bartolomé de las Casas a quien se debe de manera esencial la configuración del mito del "buen salvaje", contraposición entre indios y colonizadores, que aparece perfectamente desarrollada en su Brevisima relacion de la destrucción de las Indias (1552). A él se debe la famosa contraposición entre los "lobos" (avariciosos conquistadores españoles) y los "corderos" (inocentes indígenas) ${ }^{113}$. El auténtico modelo moral estaba representado por el indígena frente a la codicia que desvirtuaba a los cristianos europeos. No obstante no siempre esta metáfora fue interpretada en la misma dirección y el intercambio de roles fue significativo en la literatura misional jesuita del ámbito amazónico, hasta

111 Ibidem, pp. 125-126. Por supuesto los autores de tan abominable crimen no podían quedar sin el mayor castigo divino que era quitarles violentamente la vida: "La otra circunstancia es haber ya muerto violenta y desgraciadamente los parricidas todos del Padre Cipriano, siendo el más afortunado uno que murió de disentería". Ibidem, p. 127.

112 López de MARISCAL, op. cit. (nota 74), p. 207.

113 "En estas ovejas mansas y de las cualidades susodichas por su Hacedor y Criador así dotadas, entraron los españoles desde luego que las conocieron como lobos y tigres y leones crudelísimos de muchos días hambrientos", CASAS, B. DE LAS: Brevísima relación de la destrucción de las Indias, Madrid, Cátedra, 1989, pp. 76-77. 
el punto que fueron los propios jesuitas los que terminaron por encarnar el rol de la inocencia violentada por la brutalidad de unos y otros. Pero eso sí, de manera exitosa, para mayor exaltación de las glorias de la Compañía. Eso es lo que parece sentenciarnos el jesuita Diego Francisco Altamirano cuando hablaba de los misioneros jesuitas en las tierras amazónicas de los indios mojos “...como corderos entre lobos hambrientos de cuya ferocidad triunfaron, como lo había prometido nuestro Divino Redentor" "14. 